\title{
Emission inventory processing of biomass burning from a global dataset for air quality
} modeling

Ernesto Pino-Cortés $^{1 *}$, Samuel Carrasco ${ }^{1}$, Luis A. Díaz-Robles ${ }^{2}$, Francisco Cubillos ${ }^{2}$, Fidel Vallejo ${ }^{2}$, Francisco Cereceda-Balic ${ }^{3,4}$, Joshua $\mathrm{Fu}^{5}$

${ }^{1}$ Escuela de Ingeniería Química, Pontificia Universidad Católica de Valparaíso, Ave Brasil 2162, Valparaíso, Chile.

${ }^{2}$ Departamento de Ingeniería Química, Universidad de Santiago de Chile, Ave Libertador Bernardo O’Higgins 3363, Santiago de Chile, Chile.

${ }^{3}$ Centre for Environmental Technologies (CETAM), Universidad Técnica Federico Santa María, Avenida España 1680, Valparaíso, Chile

${ }^{4}$ Department of Chemistry, Universidad Técnica Federico Santa María, Avenida España 1680, Valparaíso, Chile.

${ }^{5}$ The University of Tennessee, 851 Neyland Drive, Knoxville, TN, USA.

*Corresponding author: Dr. Ernesto Pino-Cortés

Tel.: +56-32-2372609; E-Mail: ernesto.pino@pucv.cl 


\begin{abstract}
Wildfires generate large amounts of atmospheric pollutants yearly. The development of an emissions inventory for this activity is a challenge today, mainly to perform modeling of air quality. There are free available databases with historical information about this source. The main goal of this study was to process the results of biomass burning emissions for the year 2014 from the Global Fire Assimilation System (GFAS). The pollutants studied were the black carbon, the organic carbon, fine and coarse particulate matter, respectively. The inputs were pre-formatted to enter to the simulation software of the emission inventory. In this case, the Sparse Matrix Operator Kernel Emissions (SMOKE) was used and the values obtained in various cities were analyzed. As a result, the spatial distribution of the forest fire emissions in the Southern Hemisphere was achieved, with the polar stereographic projection. The highest emissions were located in the African continent, followed by the northern region of Australia. Future air quality modeling at a local level could apply the results and the methodology of this study. The biomass burning emissions could add a better performance of the results and more knowledge on the effect of this source.
\end{abstract}

Keywords: Biomass burning, SMOKE, NCO, GFASv1.3, Black carbon, Organic carbon, Southern Hemisphere 


\section{INTRODUCTION}

Biomass burning, also known as vegetation burning, is considered a significant emission source of atmospheric pollutants. Natural causes could generate it due to local conditions for ignition. It is estimated that natural fires triggered by atmospheric lightning only account for $10 \%$ of all fires (Levine 1991). Unfortunately, it also could be started intentionally by human actions. Several studies have been reported the effect of this natural source emission in climate (Thornhill et al. 2018), photochemistry of the atmosphere (Yue and Unger 2018), biogeochemical cycles (Chen et al. 2010) and human health (Apte et al. 2018).

The estimation of an air emission inventory from biomass burning is complicated due to the large spatial and temporal variability of this source at a regional scale (Kaiser et al. 2006; Andreae 2019). There are some systems which monitor and forecast air quality from satellite-based observations of the burnt area (Reid et al. 2009). It could be used to obtain regional and global fire emissions. This information is crucial in order to observe the effects of biomass burning emissions on air quality by numerical modeling. Models like CMAQ (Byun and Schere 2006), CAMx (Corporation and Way 2013), and WRFChem (Grell et al. 2005) have been used to report the transformation of air pollutants in the atmosphere. These air quality models need two essential inputs: the meteorological data and the emission inventory. The last one is usually obtained from external software like PREPCHEM-SRC (Freitas et al. 2011) and SMOKE (Baek and Seppanen 2018). Both software process the emission inventory that the user inserted as an input. SMOKE generates output files with the exact format as CMAQ or CAMx required; PREP-CHEM-SRC has been developed for WRFChem. The effect of biomass burning or wildfire on the air quality has been studied recently using numerical simulations. Table 1 summarizes some publications using various biomass burning databases for a different region of analysis. (Johnson et al. 2020) reviewed other studies, including dispersion model characteristics. Unfortunately, the processing steps of emission inventories for air quality modeling are not exposed.

Table 1 Recent studies using biomass burning and wildfires as input in air quality simulation. 


\begin{tabular}{llll}
\hline Region & $\begin{array}{l}\text { Emission inventory } \\
\text { source }\end{array}$ & $\begin{array}{l}\text { Dispersion } \\
\text { model }\end{array}$ & Reference \\
\hline USA & ICS-209 - SMARTFIRE & CMAQ & (Guan et al. 2020) \\
v2 & FireWork & GEM-MACH & (Matz et al. 2020), \\
Colombia & FINN & WRF-Chem & (Ballesteros-González et al. \\
& & WRF-Chem & (Nurzahziani et al. 2020) \\
Brazil & 3BEM, FINN & HYSPLIT & (Ojha et al. 2019) \\
India & GFAS & HYSPLIT & (Uda et al. 2019) \\
Indonesia & GFAS & HYSPLIT & (Sicard et al. 2019) \\
Spain & GFAS & CMAQ & (Uranishi et al. 2019) \\
Northeast & FINN & & \\
Asia & & HYSPLIT & (Targino et al. 2019) \\
Brazil & NSRI Brazil & NICAM & (Goto et al. 2019) \\
East Asia & GFAS & CMAQ & (Pimonsree et al. 2018) \\
Southeast & FINN & & \\
Asia & & CMAQ & (Vongruang et al. 2017) \\
Southeast & FINN - GFAS & & \\
Asia & & & \\
\hline
\end{tabular}

In order to bring accurate estimates of aerosol, reactive gas, and greenhouse gas emission fluxes to the atmospheric systems, the Global Fire Assimilation System (GFAS) was being developed by Max Planck Chemical Institute, Germany (Kaiser et al. 2012). It is established on satellite-based fire radiative power products from the MODIS instrument present in Terra and AQUA satellites. The emissions are daily published (https://permalink.aeris-data.fr/GFASv1.3), and they are inside a global map of $0.1^{\circ}$ grid resolution in the NetCDF file format.

There are many pollutants studied using this methodology, being black carbon (BC) and fine particulate matter $\left(\mathrm{PM}_{2.5}\right)$ included. $\mathrm{BC}$ is generated in an incomplete combustion process (Petzold et al. 2013), and the effects of either aerosol on climate change can only be estimated with extremely vital emissions inventories (Koch et al. 2009). Biomass burning is one of the primary 
sources of $\mathrm{BC}$ and $\mathrm{PM}_{2.5}$ worldwide (Bond et al. 2013). Due to the adverse effect of this pollutant on climate change, absorbing radiative energy, the study of $\mathrm{BC}$ in the last decades has been increasing.

During the last decade, many efforts have been developed simulating air pollutants in regional and hemispheric scales, to observe long transport in the atmosphere (Huang et al. 2015). The biomass burning in Southern Hemisphere is several and frequently, and it has been associated with particulate matter deposition in glaciers and Antarctica. (Shi et al. 2019a; Cereceda-Balic et al. 2020). Unfortunately, there is not available studies with the estimated contribution of this source in this region and it is due to the lack of information The main goal of this study was to process the results of biomass burning emissions from GFASv1.3. The NetCDF files from this database expose the emission in the unit $\mathrm{kg} \cdot \mathrm{m}^{-2} \cdot \mathrm{s}^{-1}$, which is required for processing in SMOKE. The pollutants studied were BC, organic carbon (OC), $\mathrm{PM}_{2.5}$ and coarse particulate matter $\left(\mathrm{PM}_{10}\right)$, respectively. It is a crucial step to obtain processed emissions files to simulate in air quality models mentioned before.

\section{METHODS}

The files of biomass burning of GFASv1.3 were freely downloaded from the database of the Global Emissions Initiative (www.geiacenter.org). Each pollutant's file has daily emissions from 2003 to 2016. A preprocessing stage was made to change the GFASV1.3 files format to get the input required in SMOKE. For every day, the NetCDF Operator (NCO) commands were used (Zender 2008). Details are shown in Table 2.

Table 2 Modification of GFASv1.3 files for SMOKE input requirements.

\begin{tabular}{clc}
\hline Step & NCO command & NCO statement \\
\hline 1 & ncks & ncks -d time, "number_of_file" in_file.nc out_file.nc \\
2 & ncwa & ncwa -a time in_file.nc out_file.nc
\end{tabular}


3 ncks

ncks -3 in_file.nc out_file.nc

$4 \quad$ ncpdq

ncpdq -O -h -a -lat in_file.nc out_file.nc

The first step was the extraction of the information in the period of interest (2014, January $1^{\text {st }}$ December $31^{\text {st }}$. SMOKE does not process files with variable time when NetCDF format is used as input of emission inventory. That is the reason for step 2 when the attribute time was deleted in each file generated in step 1 .

Next, in step 3, the files were formatted to classic NetCDF format as SMOKE requirement. Then, the files generated were processed in SMOKE and observed the preliminary results in VERDI, as shown in figure 1.

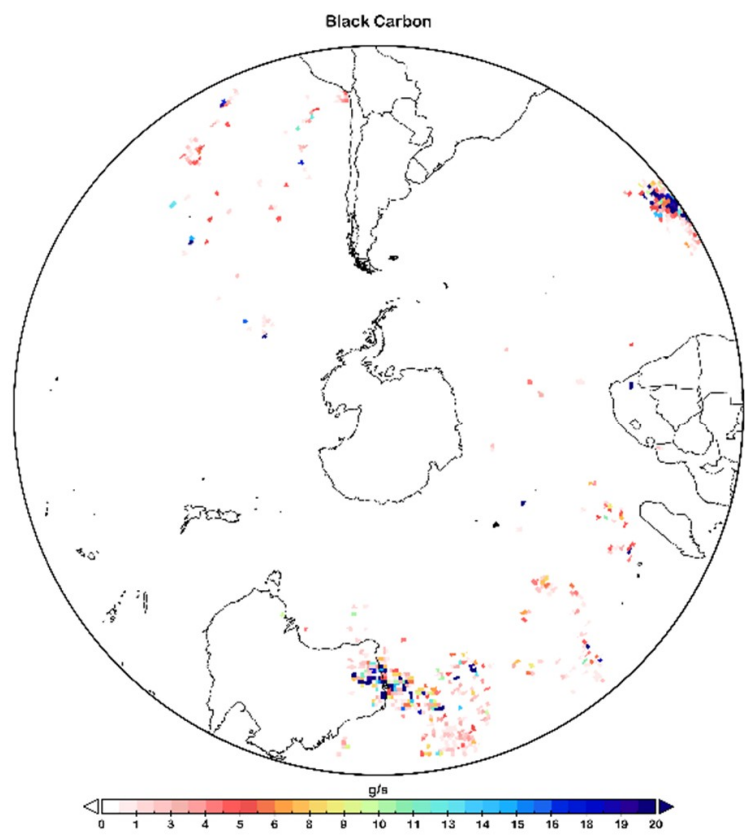

Figure 1 Emissions of black carbon obtained without step 4.

Figure 1 suggested errors in the input files due to registries in the ocean, which is impossible for biomass burning emission sources. The solution was made in step 4 when the latitude information was inverted in the file generated in step 3. Finally, the simulation in SMOKE was made for the year 2014. The emission files were centered in GWT-03 containing 180 grid cells for each side of 
the domain and $108 \mathrm{~km}$ of horizontal resolution. The hourly profile was set to constant because there is no information about it for this source. The processing steps in SMOKE and the postprocessing of the output files were recently exposed in (Pino-Cortés et al. 2020).

\section{RESULTS AND DISCUSSION}

Each output file generated in SMOKE4.5 was merged to obtain one file with all the emissions of OC, $\mathrm{BC}, \mathrm{PM}_{2.5}$, and $\mathrm{PM}_{10}$ from biomass burning for the year 2014. The highest total emissions of black and organic carbon in important cities during 2014 are shown in Fig 2.

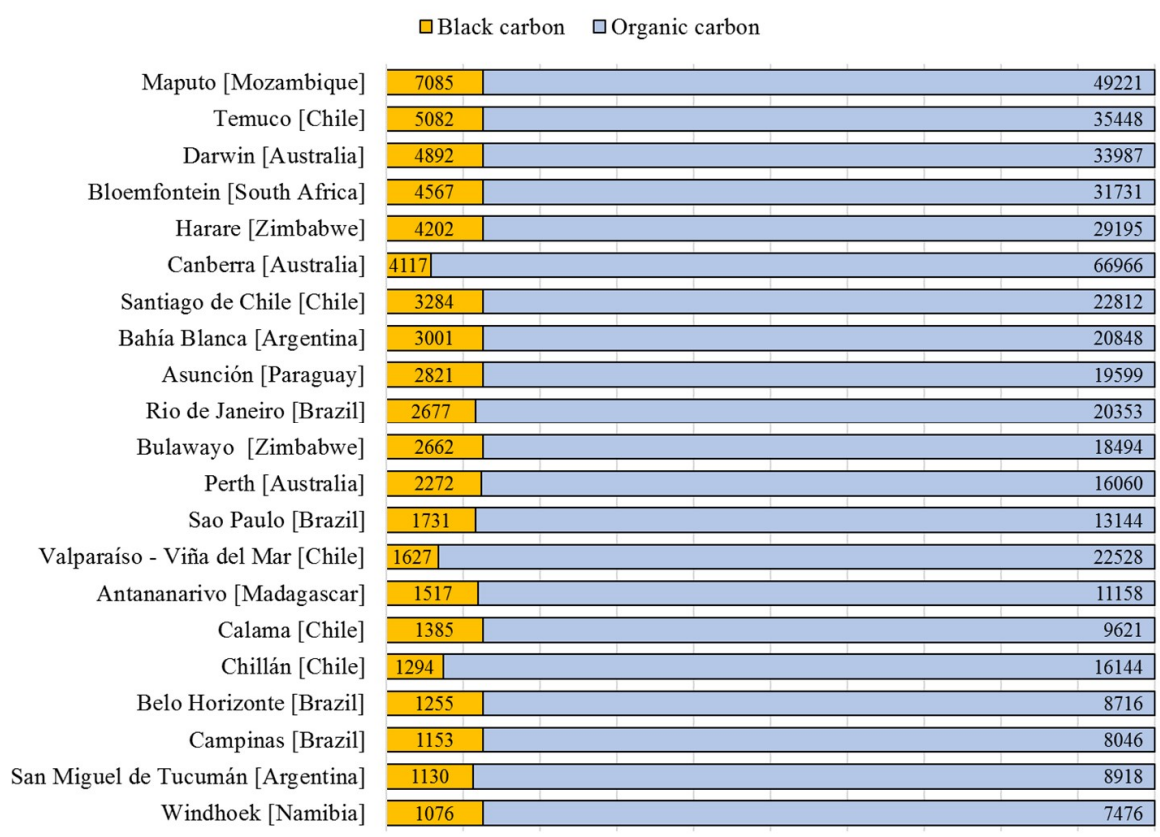

Figure 2 Highest BC and OC emissions (ton/year) during 2014.

The individual results exposed in Fig 2 cannot be compared to official reports or published papers due to the lack of information. The highest emissions of black carbon were observed in Maputo, Temuco and Darwin, in decreasing order. The registries in South America, specifically in big cities like Santiago de Chile, Asunción and Rio de Janeiro, also have high emissions of black carbon. Therefore, the organic carbon registries are incredibly high in Canberra and Maputo, compared to the rest of the cities. Also, it is remarkable the distribution of the emissions through Southern 
Hemisphere, where large registries are located in Southern America, Southern Africa and Australia. These results could tell us how forests are the main cities studied.

The OC/BC ratio is between 6 and 16, and it is in the range reported by (Ballesteros-González et al. 2020), but the minimum limit is widely distributed. The organic carbon is produced by the condensation of organic vapors generated in incomplete combustion like biomass burning. The higher ratio of $\mathrm{OC} / \mathrm{BC}$ is generated in forest and crop residues fires due to their characteristically high fuel loads (Shi et al. 2019b). In contrast, lower values are shown in savanna burning (Bond 2004). This last land type is the majority biomass burned during 2014 according to the $\mathrm{OC} / \mathrm{BC}$ ratio from GFAS emissions, and it is exposed in (Shi et al. 2020) for the same year.

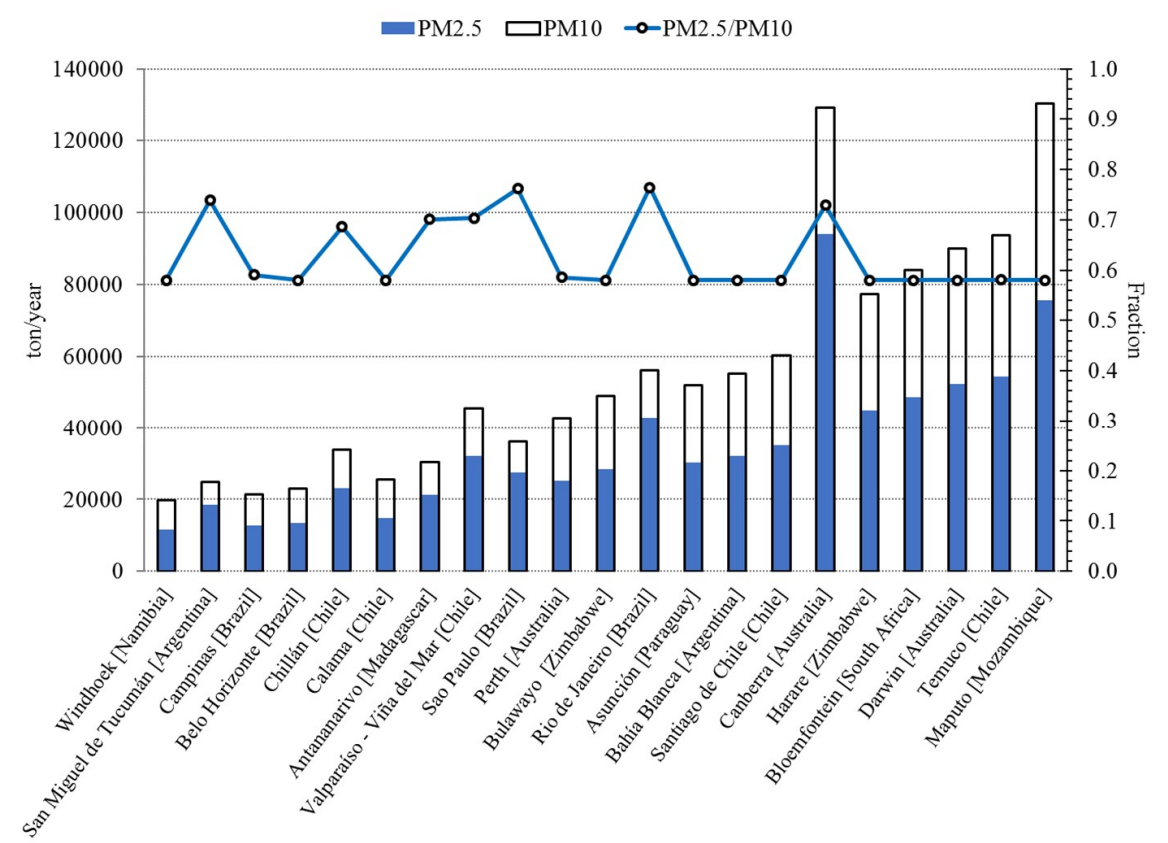

Figure 3 Highest $\mathrm{PM}_{2.5}$ and $\mathrm{PM}_{10}$ emissions during 2014.

The values in Fig 3 suggests that $\mathrm{PM}_{10}$ generated in biomass burning includes $60-75 \%$ of $\mathrm{PM}_{2.5}$. The highest values are the same as reported in Fig 2. In this case, Canberra and Maputo registered the uppermost fine and coarse particulate emission, respectively. It shows a direct relation between particulate emissions and their speciation. 
The average black carbon fraction in fine particulate matter resulted mainly in $4 \%$, but this variable could be up to $10 \%$. This result is similar to other studies (Chow et al. 2011) for this source emission. Otherwise, the $\mathrm{OC} / \mathrm{PM}_{2.5}$ ratio showed a wide range between 47 and $72 \%$. The higher values were located in Eastern Australia, New Zealand, Paraguay and Northern Argentina. In contrast, lower ratios were observed in Southeast Brazil and Eastern Madagascar. The distribution of those ratios in the domain is shown in Fig S1.

The temporal profile of the total emissions of pollutants from biomass burning is exposed for eight cities in Fig 4. This variable is useful for best knowledge of this source emission.

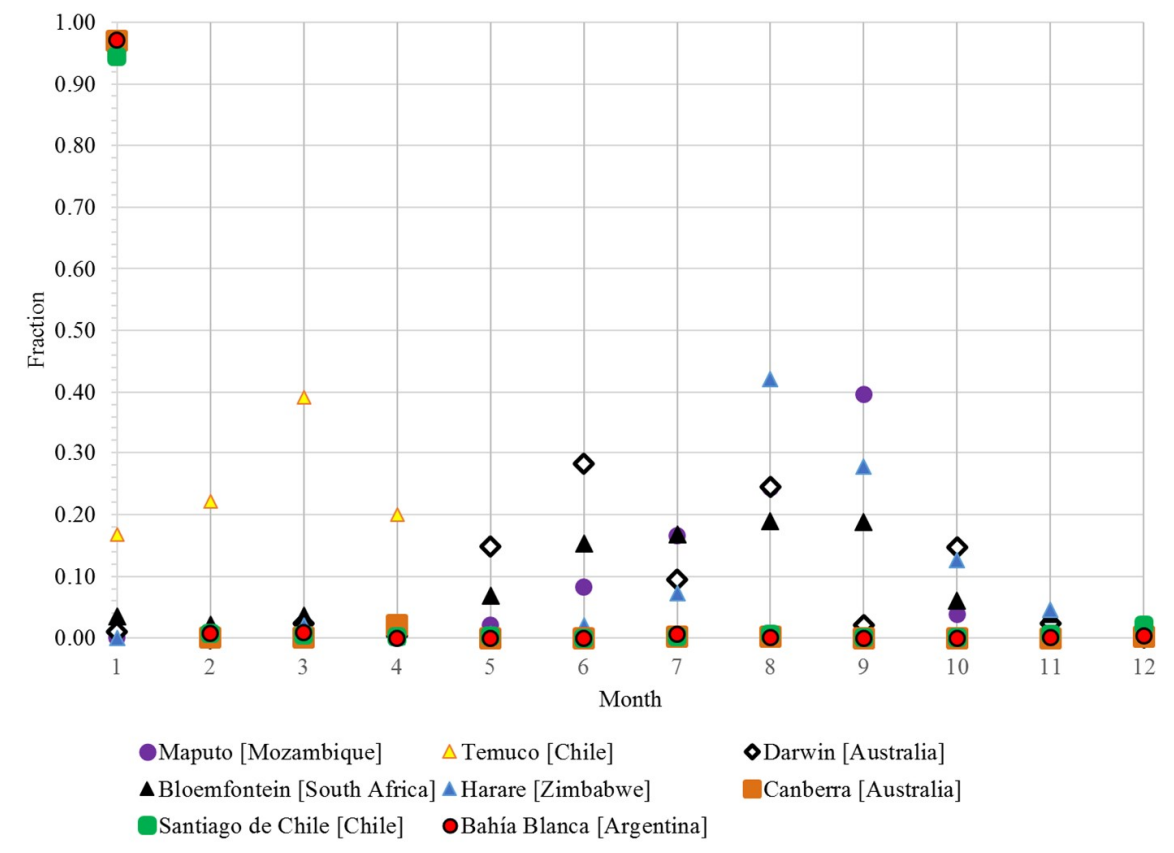

Figure 4 Monthly profile of black carbon emission during 2014.

The emissions from Santiago de Chile, Canberra and Bahia Blanca occurred up to $95 \%$ in January (Summer season in South Hemisphere). It could be explained by the direct positive effect of mean temperature and agricultural on the number of fires and burned areas. Both variables are the significant ecological predictors of fire activity in Chile (Gómez-González et al. 2019). Those results also could explain the registries in Temuco, where biomass burning emissions were registered from 
January to April (included) in 2014. African cities like Maputo and Harare registered their majority emissions from June to September. This profile was also reported by (Shi et al. 2020)

Finally, there are zones with significant emissions in the entire domain of study, as shown in Figure

5. Detailed records for many cities in Southern Hemisphere are exposed in Table S1 in Supplementary Material.
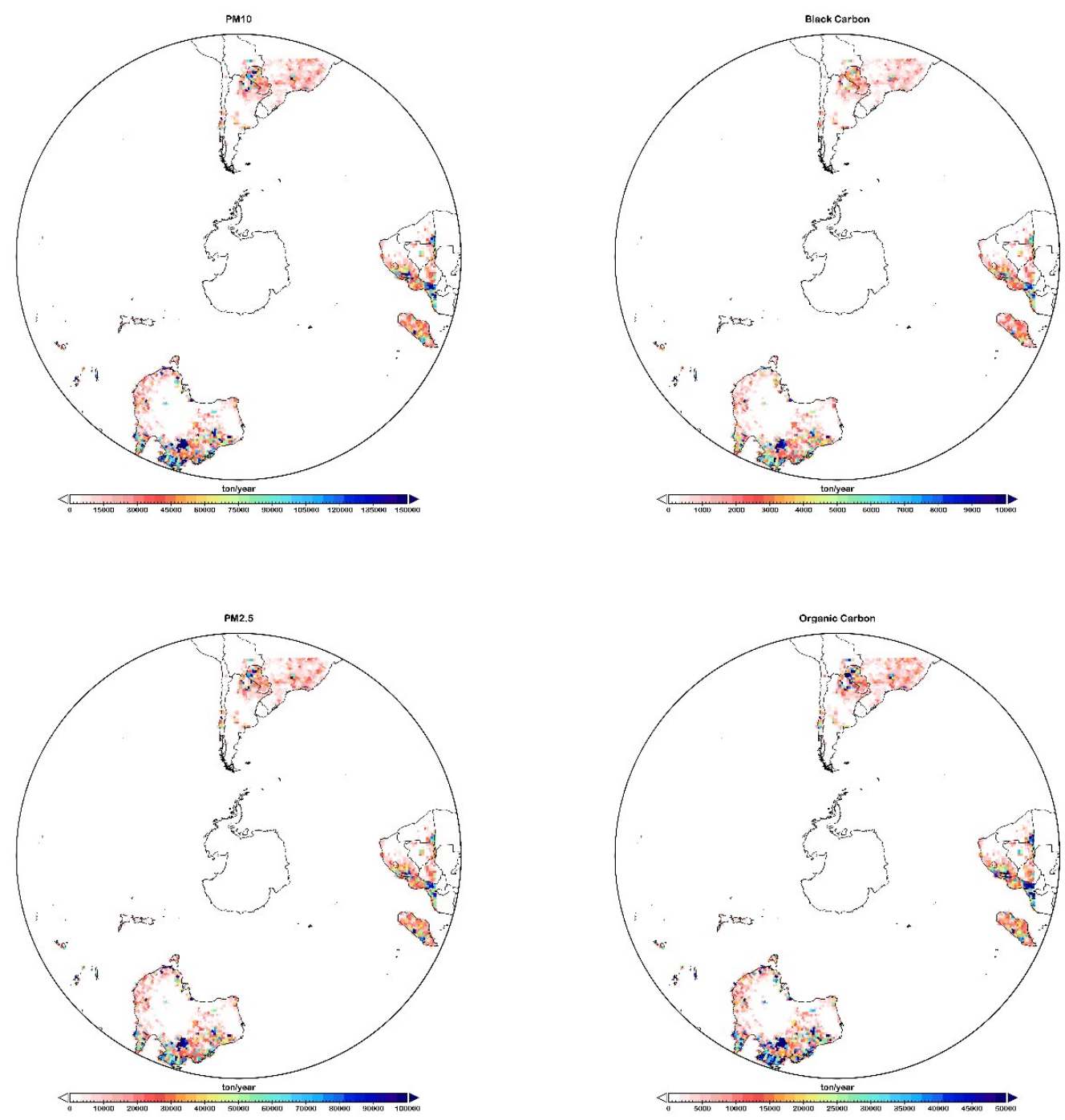

Figure 5 Annual emissions in South Hemisphere during 2014. 
The emissions were higher in the African continent. Also, the emissions in the North of Australia are highly remarkably. Both regions are affected every year by wildfire, generating higher emissions of many pollutants.

In South America, it has highlighted total emissions in the Paraguay and Northern region of Argentina, similar to reported in (Shi et al. 2020). Also, in Central-Southern areas in Chile are shown a high amount of emissions. In this country, the highest number of wildfires and burnt hectares occurred in 2014 since 1960 (Úbeda and Sarricolea 2016). Unfortunately, that study did not report the air pollutant emissions and the effect of this source is not exposed.

\section{CONCLUSION}

This study showed a practical method to process the biomass burning files from GFASv1.3 in SMOKE. The NCO commands were applied in four steps to change them to obtain the required format as NetCDF input.

The results and the methodology exposed could bring important information to Southern Hemisphere countries, especially in highly populated cities with several episodes with high air quality index of pollution. Also, national emission inventories could be improved, and future air quality modeling could be applied. The biomass burning emissions could add a better performance of the results and more knowledge on the effect of this source.

\section{ACKNOWLEDGMENTS}

This work was partially supported by Beca Doctorado Nacional, Folio 21150125, ANID; the supercomputing infrastructure at NLHPC (ECM-02). We acknowledge ECCAD for the archiving and distribution of the data

\section{REFERENCES}

1. Andreae MO (2019) Emission of trace gases and aerosols from biomass burning -- an 
updated assessment. Atmospheric Chemistry and Physics 19:8523-8546.

https://doi.org/10.5194/acp-19-8523-2019

2. Apte JS, Brauer M, Cohen AJ, et al (2018) Ambient PM2.5 Reduces Global and Regional Life Expectancy. Environmental Science \& Technology Letters 5:546-551. https://doi.org/10.1021/acs.estlett.8b00360

3. Baek BH, Seppanen C (2018) Spare Modeling Operator Kerner Emissions (SMOKE) Modeling System. https://doi.org/10.5281/ZENODO.1421403

4. Ballesteros-González K, Sullivan AP, Morales-Betancourt R (2020) Estimating the air quality and health impacts of biomass burning in northern South America using a chemical transport model. Science of the Total Environment 739:139755.

https://doi.org/10.1016/j.scitotenv.2020.139755

5. Bond TC (2004) A technology-based global inventory of black and organic carbon emissions from combustion. Journal of Geophysical Research 109:D14203. https://doi.org/10.1029/2003JD003697

6. Bond TC, Doherty SJ, Fahey DW, et al (2013) Bounding the role of black carbon in the climate system: A scientific assessment. Journal of Geophysical Research: Atmospheres 118:5380-5552. https://doi.org/10.1002/jgrd.50171

7. Byun D, Schere KL (2006) Review of the Governing Equations, Computational Algorithms, and Other Components of the Models-3 Community Multiscale Air Quality (CMAQ) Modeling System. Applied Mechanics Reviews 59:51-77

8. Cereceda-Balic F, Vidal V, Ruggeri MF, González HE (2020) Black carbon pollution in snow and its impact on albedo near the Chilean stations on the Antarctic peninsula: First results. Science of The Total Environment 743:140801. https://doi.org/https://doi.org/10.1016/j.scitotenv.2020.140801

9. Chen L-WA, Verburg P, Shackelford A, et al (2010) Moisture effects on carbon and nitrogen emission from burning of wildland biomass. Atmospheric Chemistry and Physics 
10:6617-6625. https://doi.org/10.5194/acp-10-6617-2010

10. Chow JC, Watson JG, Lowenthal DH, et al (2011) PM2.5 source profiles for black and organic carbon emission inventories. Atmospheric Environment 45:5407-5414. https://doi.org/10.1016/j.atmosenv.2011.07.011

11. Corporation EI, Way R (2013) Air Pollution Modelling and Simulation. Air Pollution Modelling and Simulation. https://doi.org/10.1007/978-3-662-04956-3

12. Freitas SR, Longo KM, Alonso MF, et al (2011) PREP-CHEM-SRC - 1.0: A preprocessor of trace gas and aerosol emission fields for regional and global atmospheric chemistry models. Geoscientific Model Development 4:419-433. https://doi.org/10.5194/gmd-4-4192011

13. Gómez-González S, González ME, Paula S, et al (2019) Temperature and agriculture are largely associated with fire activity in Central Chile across different temporal periods. Forest Ecology and Management 433:535-543. https://doi.org/10.1016/j.foreco.2018.11.041

14. Goto D, Kikuchi M, Suzuki K, et al (2019) Aerosol model evaluation using two geostationary satellites over East Asia in May 2016. Atmospheric Research 217:93-113. https://doi.org/https://doi.org/10.1016/j.atmosres.2018.10.016

15. Grell GA, Peckham SE, Schmitz R, et al (2005) Fully coupled "online" chemistry within the WRF model. Atmospheric Environment 39:6957-6975. https://doi.org/https://doi.org/10.1016/j.atmosenv.2005.04.027

16. Guan S, Wong DC, Gao Y, et al (2020) Impact of wildfire on particulate matter in the southeastern United States in November 2016. Science of The Total Environment 724:138354. https://doi.org/https://doi.org/10.1016/j.scitotenv.2020.138354

17. Huang K, Fu JS, Prikhodko VY, et al (2015) Russian anthropogenic black carbon: Emission reconstruction and Arctic black carbon simulation. Journal of Geophysical Research: Atmospheres 120:11,306-311,333. https://doi.org/10.1002/2015JD023358 
18. Johnson AL, Abramson MJ, Dennekamp M, et al (2020) Particulate matter modelling techniques for epidemiological studies of open biomass fire smoke exposure: a review. Air Quality, Atmosphere and Health 13:35-75. https://doi.org/10.1007/s11869-019-00771-z

19. Kaiser JW, Heil A, Andreae MO, et al (2012) Biomass burning emissions estimated with a global fire assimilation system based on observed fire radiative power. Biogeosciences 9:527-554. https://doi.org/10.5194/bg-9-527-2012

20. Kaiser JW, Schultz MG, Grégoire JM, et al (2006) Observation Requirements for Global Biomass Burning Emission Monitoring. Change 1-8

21. Koch D, Schulz M, Kinne S, et al (2009) Evaluation of black carbon estimations in global aerosol models. Atmospheric Chemistry and Physics 9:9001-9026. https://doi.org/10.5194/acp-9-9001-2009

22. Levine JS (1991) Biomass Burning: Its History, Use, and Distribution and Its Impact on Environmental Quality and Global Climate. In: Global Biomass Burning: Atmospheric, Climatic, and Biospheric Implications. MITP, p 1

23. Matz CJ, Egyed M, Xi G, et al (2020) Health impact analysis of PM2.5 from wildfire smoke in Canada (2013-2015, 2017-2018). Science of The Total Environment 725:138506. https://doi.org/https://doi.org/10.1016/j.scitotenv.2020.138506

24. Nurzahziani, Surussavadee C, Noosook T (2020) High-Resolution Biomass Burning Aerosol Transport Simulations in the Tropics. Atmosphere 11

25. Ojha N, Girach I, Sharma K, et al (2019) Surface ozone in the Doon Valley of the Himalayan foothills during spring. Environmental Science and Pollution Research 26:19155-19170. https://doi.org/10.1007/s11356-019-05085-2

26. Petzold A, Ogren JA, Fiebig M, et al (2013) Recommendations for reporting black carbon measurements. Atmospheric Chemistry and Physics 13:8365-8379. https://doi.org/10.5194/acp-13-8365-2013

27. Pimonsree S, Vongruang P, Sumitsawan S (2018) Modified biomass burning emission in 
modeling system with fire radiative power: Simulation of particulate matter in Mainland Southeast Asia during smog episode. Atmospheric Pollution Research 9:133-145. https://doi.org/https://doi.org/10.1016/j.apr.2017.08.002

28. Pino-Cortés E, Carrasco S, Díaz-Robles LA, et al (2020) Black and organic carbon fractions in fine particulate matter by sectors in the South Hemisphere emissions for decision-making on climate change and health effects. Environmental Science and Pollution Research. https://doi.org/10.1007/s11356-020-10164-w

29. Reid JS, Hyer EJ, Prins EM, et al (2009) Global Monitoring and Forecasting of BiomassBurning Smoke: Description of and Lessons From the Fire Locating and Modeling of Burning Emissions (FLAMBE) Program. IEEE Journal of Selected Topics in Applied Earth Observations and Remote Sensing 2:144-162. https://doi.org/10.1109/JSTARS.2009.2027443

30. Shi G, Wang X-C, Li Y, et al (2019a) Organic tracers from biomass burning in snow from the coast to the ice sheet summit of East Antarctica. Atmospheric Environment 201:231241. https://doi.org/https://doi.org/10.1016/j.atmosenv.2018.12.058

31. Shi Y, Zang S, Matsunaga T, Yamaguchi Y (2020) A multi-year and high-resolution inventory of biomass burning emissions in tropical continents from 2001-2017 based on satellite observations. Journal of Cleaner Production 270:122511. https://doi.org/10.1016/j.jclepro.2020.122511

32. Shi Y, Zhao A, Matsunaga T, et al (2019b) High-resolution inventory of mercury emissions from biomass burning in tropical continents during 2001-2017. Science of The Total Environment 653:638-648. https://doi.org/https://doi.org/10.1016/j.scitotenv.2018.10.420

33. Sicard M, Granados-Muñoz MJ, Alados-Arboledas L, et al (2019) Ground/space, passive/active remote sensing observations coupled with particle dispersion modelling to understand the inter-continental transport of wildfire smoke plumes. Remote Sensing of Environment 232:111294. https://doi.org/10.1016/j.rse.2019.111294 
34. Targino AC, Harrison RM, Krecl P, et al (2019) Surface ozone climatology of South Eastern Brazil and the impact of biomass burning events. Journal of Environmental Management 252:109645. https://doi.org/https://doi.org/10.1016/j.jenvman.2019.109645

35. Thornhill GD, Ryder CL, Highwood EJ, et al (2018) The effect of South American biomass burning aerosol emissions on the regional climate. Atmospheric Chemistry and Physics 18:5321-5342. https://doi.org/10.5194/acp-18-5321-2018

36. Úbeda X, Sarricolea P (2016) Wildfires in Chile: A review. Global and Planetary Change 146:152-161. https://doi.org/https://doi.org/10.1016/j.gloplacha.2016.10.004

37. Uda SK, Hein L, Atmoko D (2019) Assessing the health impacts of peatland fires: a case study for Central Kalimantan, Indonesia. Environmental Science and Pollution Research 26:31315-31327. https://doi.org/10.1007/s11356-019-06264-x

38. Uranishi K, Ikemori F, Shimadera H, et al (2019) Impact of field biomass burning on local pollution and long-range transport of PM2.5 in Northeast Asia. Environmental Pollution 244:414-422. https://doi.org/https://doi.org/10.1016/j.envpol.2018.09.061

39. Vongruang P, Wongwises P, Pimonsree S (2017) Assessment of fire emission inventories for simulating particulate matter in Upper Southeast Asia using WRF-CMAQ. Atmospheric Pollution Research 8:921-929. https://doi.org/https://doi.org/10.1016/j.apr.2017.03.004

40. Yue X, Unger N (2018) Fire air pollution reduces global terrestrial productivity. Nature Communications 9:5413. https://doi.org/10.1038/s41467-018-07921-4

41. Zender CS (2008) Analysis of self-describing gridded geoscience data with netCDF Operators (NCO). Environmental Modelling \& Software 23:1338-1342. https://doi.org/10.1016/J.ENVSOFT.2008.03.004 